\title{
Emergence of carbapenem-resistant Escherichia coli producing CMY-2-type AmpC $\beta$-lactamase in Brazil
}

Carbapenem-resistant Escherichia coli isolates have not been described to date in South America. However, the emergence of Shigella flexneri and Klebsiella pneumoniae isolates producing CMY-2type plasmid-mediated AmpC was recently reported in Argentina (Radice et al., 2007; Rapoport et al., 2008). Here, we report the emergence of carbapenemresistant E. coli producing CMY-2-type AmpC $\beta$-lactamase in Brazil, confirming that CMY-2-producing strains have already become established in Latin America.

From June to August 2007, four multidrug-resistant (MDR) E. coli strains (EC1-EC4), susceptible only to aminoglycosides, were isolated successively from blood, abdominal drain fluid and catheter-tip cultures from a 46-year-old man hospitalized at the Hospital Beneficiência Portuguesa (HBP), São Paulo, southern Brazil. The patient, who had undergone total colectomy, was admitted to the HBP in 2005 for reconstruction of the digestive tract. A few months later, he developed sclerosing cholangitis and liver cirrhosis, requiring liver transplantation, which was performed in May 2007. On the 7th postoperative day after transplantation, the patient developed a catheter-related infection caused by oxacillin-resistant Staphylococcus aureus, which was treated with vancomycin and piperacillin/tazobactam. On June 13, a MDR E. coli strain (EC1) was isolated from an abdominal drain fluid culture, which was also positive for Candida albicans. The patient was then treated with imipenem, vancomycin and fluconazole for 21 days and underwent surgery to wash out the abdominal cavity of blood and pus. On July 16 , the patient presented severe gastrointestinal bleeding with acute renal failure, developing a hydroelectrolytic balance disorder. Nine days later, an intrahepatic abscess was identified and a second MDR E. coli strain (EC2) was recovered from blood culture. In August
2007, another two MDR E. coli isolates

(EC3 and EC4) were recovered from blood and catheter-tip cultures, respectively. Unfortunately, despite receiving parenteral polymyxin B treatment, the patient died due to multiple organ failure as a result of septicaemia.

The identification and antimicrobial susceptibility profiles of $E$. coli isolates were determined using the VITEK system (bioMérieux). MICs were subsequently determined using an agar dilution method (CLSI, 2005) and Etest (AB Biodisk). The E. coli EC1-EC4 strains were resistant to extended-spectrum cephalosporins, cefoxitin, aztreonam, carbapenems, ciprofloxacin and trimethoprimsulfamethoxazole, and remained insensitive to clinically available inhibitors, showing susceptibility only to aminoglycosides (Table 1). To elucidate the mechanism involved in carbapenem resistance, firstly the hydrolysis of imipenem was evaluated by bioassay, as described previously (Lincopan et al., 2005). Next, a double-disc synergy test (DDST) using specific $\beta$-lactam inhibitors [2-mercaptopropionic acid, 2mercaptoacetic acid, EDTA and aminophenylboronic acid (APB)] was employed to screen for metallo- and plasmid-mediated AmpC $\beta$-lactamases (Arakawa et al., 2000; Doi \& Paterson, 2007). Additionally, a disc potentiation test (DPT) was performed with APB (Doi \& Paterson, 2007). Hydrolysis of imipenem was not detected for any of the isolates. Moreover, imipenemase activity was not inhibited by thiol compounds or EDTA. However, AmpC production was assessed by a positive DDST using piperacillin/tazobactam and cefepime as substrate and APB as inhibitor. Addition of APB to a ceftazidime-containing disc in the DPT resulted in a zone enlargement from 0 to $20 \mathrm{~mm}$, which was taken as a positive result, but, curiously, addition of ABP to cefoxitin-containing discs failed to inhibit AmpC activity (Table 1). DNA amplification by PCR was used to search for $b l a_{\mathrm{CTX}-\mathrm{M}}, b l a_{\mathrm{TEM}}, b l a_{\mathrm{SHV}}$ and $b l a_{\mathrm{PER}-2}$ ESBL genes, $b l a_{\mathrm{IMP}}, b l a_{\mathrm{VIM}}, b l a_{\mathrm{SPM}}$ and $b l a_{\mathrm{KPC}}$ carbapenemase genes and $b l a_{\mathrm{DHA}-1}$, $b l a_{\mathrm{DHA}-2} b l a_{\mathrm{CMY}-1} b l a_{\mathrm{CMY}-2}, b l a_{\mathrm{FOX}}$ and $b l a_{\mathrm{MIR} / \mathrm{ACT}}$ plasmid-mediated AmpC genes. PCR screening revealed the presence of both $b l a_{\mathrm{TEM}}$ and $b l a_{\mathrm{CMY}-2}$-like genes in all isolates. Nucleotide sequencing showed that the $b l a_{\mathrm{CMY}-2}$ gene (GenBank accession no. EU531728) had $99 \%$ sequence identity with the plasmid-encoded $b l a_{\mathrm{CMY}-2}$ gene first described in K. pneumoniae in Greece (Bauernfeind et al., 1996). Although the presence of plasmid was verified in all MDR E. coli strains, transformation of plasmid DNA into E. coli DH5 $\alpha$, and conjugation experiments between the clinical isolates EC1-EC4 and E. coli K-12, were unsuccessful. Epidemiological typing of E. coli isolates was performed by ERICPCR. Genotyping revealed that the four E. coli isolates were clonally related, showing identical band profiles. Finally, the outermembrane proteins (OMPs) of carbapenem-resistant E. coli isolates were extracted and analysed by SDS-PAGE, and compared with profiles of carbapenemsusceptible E. coli control strains K-12 and ATCC 25922. Carbapenem-resistant isolates lacked a $36 \mathrm{kDa}$ OMP that was present in the carbapenem-susceptible isolates. In fact, OMP profiles of E. coli K12 and E. coli ATCC 25922 strains showed expression of 35 and $36 \mathrm{kDa}$ porins, as described previously (Liu et al., 2008; Poirel et al., 2004). In this respect, two major porins, $\mathrm{OmpF}$ and $\mathrm{OmpC}$ (homologous to the OmpK35 and OmpK36 porins, respectively, from $K$. pneumoniae), have been described in $E$. coli, and the loss or diminished expression of either of these two porins has been related to resistance to imipenem, meropenem, ertapenem and cefoxitin (Clarke et al., 2003; Lartigue et al., 2007; Liu et al., 2008).

In summary, our preliminary results show that CMY-2 production coupled with loss 
Table 1. Susceptibility profiles, AmpC screening and genotyping analyses of porin-deficient $E$. coli producing CMY-2-type AmpC $\beta$-lactamase

\begin{tabular}{|c|c|c|c|c|c|c|c|c|c|c|c|c|c|c|}
\hline \multirow[t]{2}{*}{ Strain } & \multicolumn{10}{|c|}{ Antimicrobial susceptibility profile $\mathrm{MIC}\left(\mathrm{mg} \mathrm{l}^{-1}\right)^{\star}$} & \multicolumn{2}{|c|}{$\begin{array}{c}\text { AmpC screening } \\
\text { DPT }(\mathrm{mm}) \dagger\end{array}$} & \multirow[t]{2}{*}{ PCR bla genes } & \multirow[t]{2}{*}{$\begin{array}{l}\text { ERIC } \\
\text { profile }\end{array}$} \\
\hline & AZT & CAZ & FOX & CEP & $\begin{array}{c}\text { CT/ } \\
+ \text { CLA }\end{array}$ & $\begin{array}{c}\text { IMP/ } \\
+ \text { EDTA }\end{array}$ & ERT & MER & CIP & AK & $\begin{array}{l}\mathrm{CAZ/} \\
+\mathrm{APB}\end{array}$ & $\begin{array}{l}\text { FOX/ } \\
+\mathrm{APB}\end{array}$ & & \\
\hline $\mathrm{EC} 1$ & $>256$ & $>256$ & $>256$ & 32 & $>16 />1$ & $24 / 8$ & 128 & 16 & $>32$ & 4 & $0 / 20$ & $0 / 0$ & $\begin{array}{c}b l a_{\mathrm{TEM}}-\text { like, } \\
b l a_{\mathrm{CMY}-2}\end{array}$ & A \\
\hline EC3 & $>256$ & $>256$ & $>256$ & 64 & $>16 />1$ & $32 / 24$ & 256 & 32 & $>32$ & 6 & $0 / 20$ & $0 / 0$ & $\begin{array}{c}b l a_{\mathrm{TEM}} \text {-like, } \\
b l a_{\mathrm{CMY}-2}\end{array}$ & A \\
\hline EC4 & $>256$ & $>256$ & $>256$ & 64 & $>16 />1$ & $24 / 8$ & 128 & 16 & $>32$ & 6 & $0 / 20$ & $0 / 0$ & $\begin{array}{c}b l a_{\mathrm{TEM}}-\text { like } \\
b l a_{\mathrm{CMY}-2}\end{array}$ & A \\
\hline
\end{tabular}

*AZT, Aztreonam; CAZ, ceftazidime; FOX, cefoxitin; CEP, cefepime; CT/ + CLA, cefotaxime/cefotaxime-clavulanic acid; IMP/ + EDTA, imipenem/ imipenem-EDTA; ERT, ertapenem; MER, meropenem; CIP, ciprofloxacin; AK, amikacin.

$\dagger \mathrm{DPT}$, Disc potentiation test (diameter inhibition, mm); CAZ/ + APB, ceftazidime/ceftazidime-aminophenylboronic acid (400 $\mu \mathrm{g}$ per disc); FOX/ $+\mathrm{APB}$, cefoxitin/cefoxitin-aminophenylboronic acid (400 $\mu \mathrm{g}$ per disc).

of a $36 \mathrm{kDa}$ OMP conferred a high level of resistance to carbapenems (mainly ertapenem), extended-spectrum cephalosporins and cefoxitin upon the E. coli isolates, contributing to treatment failure and death of the patient. This interplay between absence of porin and CMY-2-type AmpC expression in carbapenem-resistant E. coli has been previously reported in the literature (Liu et al., 2008; Mammeri et al., 2008; Poirel et al., 2004). However, in Latin America this appears to be an emerging phenomenon, since carbapenem resistance in members of the Enterobacteriaceae has only been associated with the production of IMP-1 and KPC-2 enzymes (Lincopan et al., 2006; Villegas et al., 2006; Pasteran et al., 2008). Regarding CMY-type cephamycinases, since the first description of CMY-1 in 1989, 36 CMY-variant enzymes have been reported worldwide (http://www.lahey.org/studies/), with the CMY-2 variant being the most prevalent and most widely distributed so far (Liu et al., 2008; Poirel et al., 2004; Rapoport et al., 2008).

We underline the need for continuous surveillance of the prevalence and evolution of carbapenem-resistant isolates producing AmpC $\beta$-lactamase in Brazil. Dissemination of plasmid-mediated AmpC enzymes may become an important public health issue in South America.

\section{Acknowledgements}

FAPESP and $\mathrm{CNPq}$ research grants are gratefully acknowledged.

\section{Mónica Pavez, ${ }^{1}$ Patrícia Neves, ${ }^{1}$ Milena Dropa, ${ }^{2}$ Maria H. Matté, ${ }^{2}$ Renato S. Grinbaum, ${ }^{3}$ Maria R. Elmor de Araújo, ${ }^{3}$ Elsa M. Mamizuka ${ }^{1}$ and Nilton Lincopan ${ }^{1,4}$}

${ }^{1}$ Laboratory of Clinical Microbiology, School of Pharmacy, University of São Paulo, CP 66083, São Paulo, SP, Brazil

${ }^{2}$ School of Public Health, University of São Paulo, Avenida Doutor Arnaldo 715, São Paulo, SP, Brazil

${ }^{3}$ Laboratory of Clinical Microbiology and Infectious Diseases Team, Hospital Beneficiência Portuguesa, São Paulo, Brazil

${ }^{4}$ Institute of Biomedical Sciences, Department of Microbiology, University of São Paulo, São Paulo, Brazil

Correspondence: Nilton Lincopan (lincopan@usp.br)

Arakawa, Y., Shibata, N., Shibayama, K., Kurokawa, H., Yagi, T., Fujiwara, H. \& Goto, M. (2000). Convenient test for screening metallobeta-lactamase-producing Gram-negative bacteria by using thiol compounds. J Clin Microbiol 38, 40-43.

Bauernfeind, A., Stemplinger, I., Jungwirth, R. \& Giamarellou, H. (1996). Characterization of the plasmidic beta-lactamase CMY-2, which is responsible for cephamycin resistance. Antimicrob Agents Chemother 40, 221-224.

Clarke, B., Hiltz, M., Musgrave, H. \& Forward, K. R. (2003). Cephamycin resistance in clinical isolates and laboratory-derived strains of Escherichia coli, Nova Scotia, Canada. Emerg Infect Dis 9, 1254-1259.

CLSI (2005). Methods for Dilution Antimicrobial Susceptibility Tests for Bacteria that Grow Aerobically; Approved Standard. CLSI document M7-A6, 6th edn. Wayne, PA: Clinical and Laboratory Standards Institute.

Doi, Y. \& Paterson, D. L. (2007). Detection of plasmid-mediated class $\mathrm{C}$ beta-lactamases. Int $\mathrm{J}$ Infect Dis 11, 191-197.

Lartigue, M. F., Poirel, L., Poyart, C., RéglierPoupet, H. \& Nordmann, P. (2007). Ertapenem resistance of Escherichia coli. Emerg Infect Dis 13, 315-317.

Lincopan, N., McCulloch, J. A., Reinert, C., Cassettari, V. C., Gales, A. C. \& Mamizuka, E. M. (2005). First isolation of metallo- $\beta$-lactamaseproducing multiresistant Klebsiella pneumoniae from a patient in Brazil. J Clin Microbiol 43, 516-519.

Lincopan, N., Leis, R., Vianello, M. A., de Araújo, M. R., Ruiz, A. S. \& Mamizuka, E. M. (2006). Enterobacteria producing extended-spectrum beta-lactamases and IMP-1 metallo-betalactamases isolated from Brazilian hospitals. J Med Microbiol 55, 1611-1613.

Liu, Y. F., Yan, J. J., Ko, W. C., Tsai, S. H. \& Wu, J. J. (2008). Characterization of carbapenemnon-susceptible Escherichia coli isolates from a university hospital in Taiwan. J Antimicrob Chemother 61, 1020-1023.

Mammeri, H., Nordmann, P., Berkani, A. \& Eb, F. (2008). Contribution of extendedspectrum AmpC (ESAC) beta-lactamases to 
carbapenem resistance in Escherichia coli. FEMS Microbiol Lett 282, 238-240.

Pasteran, F. G., Otaegui, L., Guerriero, L., Radice, G., Maggiora, R., Rapoport, M., Faccone, D., Di Martino, A. \& Galas, M. (2008). Klebsiella pneumoniae carbapenenemase-2, Buenos Aires, Argentina. Emerg Infect Dis 14, 1178-1180.

Poirel, L., Héritier, C., Spicq, C. \& Nordmann, P. (2004). In vivo acquisition of high-level resistance to imipenem in Escherichia coli. J Clin Microbiol 42, 3831-3833.
Radice, M., Cittadini, R., Stortz, M., Ruggiero, M., Gutkind, G. \& Vay, C. (2007). Emergence of plasmid-mediated AmpC $\beta$-lactamases in ESBLproducing enterobacteria in Buenos Aires, Argentina. In Abstracts of the 47th Interscience Conference on Antimicrobial Agents and Chemotherapy, Washington, DC, 17-20 September 2007, p. 131. Washington, DC: American Society for Microbiology.

Rapoport, M., Monzani, V., Pasteran, F., Morvay, L., Faccone, D., Petroni, A. \& Galas, M. (2008).
CMY-2-type plasmid-mediated AmpC betalactamase finally emerging in Argentina. Int $J$ Antimicrob Agents 31, 385-387.

Villegas, M. V., Lolans, K., Correa, A., Suarez, C. J., Lopez, J. A., Vallejo, M., Quinn, J. P.; Colombian Nosocomial Resistance Study Group (2006). First detection of the plasmidmediated class A carbapenemase KPC-2 in clinical isolates of Klebsiella pneumoniae from South America. Antimicrob Agents Chemother 50, 2880-2882. 